\title{
Impact of Magnetic Treatment of Irrigation Water on the Growth and Yield of Tomato
}

\author{
Kamorudeen Olaniyi YUSUF*, Ayodele Olanrewaju OGUNLELA
}

University of Ilorin, Department of Agricultural and Biosystems Engineering, Ilorin, Nigeria; yusuf.ok@unilorin.edu.ng(*correspondingauthor)

\begin{abstract}
This study was carried out to determine whether magnetic treatment of the irrigation water may actually enhance vegetative growth and yield of tomato. Three magnetic flux densities of 124,319 and $719 \mathrm{G}$ (treatments $\mathrm{T}_{1}, \mathrm{~T}_{2}$ and $\mathrm{T}_{3}$ ) were used to treat the water and a control experiment $(\mathrm{Tc})$ which was irrigated with non-magnetically treated water was also set up. The magnetic field was produced by an electromagnet that had a variable voltage unit varying the voltage from 4 to $12 \mathrm{~V}$. The tomato were planted in buckets, kept in a transparent garden shed for 130 days and irrigated with magnetically treated water and non-magnetically treated water. A completely randomized design experimental layout was used in this study and each of the three treatments was replicated seven times. The results indicated that tomato crop irrigated with magnetically treated water grew faster than that of the non-magnetically treated water and the stem diameters were bigger than those of control. The heights of tomato plants $\left(T_{1}, T_{2} T_{3}\right.$ and $\left.T c\right)$ after 47 days were 560.0, 556.4, 588.6 and $469.3 \mathrm{~mm}$ respectively. The total yield after 130 days of survey for $T_{1}, T_{2} T_{3}$ and $T c$ were 892.1, 1075.8, 1045.7 and $637.7 \mathrm{~g}$ respectively. The percentage increment in yield from the plants treated with magnetically treated water varied from 39.9 to $68.7 \%$ compared to the yield from untreated water.
\end{abstract}

Keywords: crop booster, irrigation, magnetically treated water, voltage

\section{Introduction}

The use of magnetic field for the treatment of water is still a controversy issue especially in the Western world and Asian countries. Some researchers agreed that magnetic treatment of irrigation water can increase the crop yield (Podlesny et al., 2004; Moussa, 2011; Chern, 2012). There are several studies indicating that magnetic treatment of irrigation water offered many benefits in agriculture such as increased yield, water economy, early maturity of crops, reduced plant diseases, improved crop quality, increased fertilizers' efficiency and reduced cost of farm operations (Kronenberg, 1985; Maheshwari and Grewal, 2009; Babu, 2010; Hozayn and Qados, 2010; Suchitra and Babu, 2011).

Magnetic field may actually change the structure of water, thereby reducing surface tension, increase minerals' dissolvability and provide adequate nutrients for plant growth (Babu, 2010). When water passes through a magnetic field, its structure and some physical characteristic such as density, salt solution capacity and deposition ratio of solid particles are to be changed (Higashitani et al., 1993).

Anand et al. (2012) indicated that magnetic treatment of irrigation water alleviated adverse effect of water stress as it reduced free radicals production and antioxidant enzymes activity. Moussa (2011) concluded that magnetically treated water with 3,000 G improved quantity and quality of common bean crop. He pointed that magnetic water could stimulate the defence system of plants, photosynthetic activity and translocation efficiency of photoassimilates. Noran et al.
(1996) also confirmed the assumption that as a result of the influence of the magnetic field on solutes, the interaction between soil particles and salts dissolved in ordinary water did not resemble the interaction between the soil particles and the salts dissolved in magnetically treated water. Muraji $e t$ al. (1998) discovered that there was an enhancement in root growth of maize (Zea mays) by exposing the maize seedling to $50 \mathrm{G}$ magnetic fields at alternating frequencies of $40-160 \mathrm{~Hz}$. However, there was a reduction in primary root growth of maize plants grown in a magnetic field alternating at 240-320 $\mathrm{Hz}$. The highest growth rate of maize roots was achieved in a magnetic field of $50 \mathrm{G}$ at $10 \mathrm{~Hz}$. Kochmarsky (1996) also applied a magnetic flux density for water treatment ranging from 1,000 to $6,000 \mathrm{G}$. Chern (2012) used permanent magnet with magnetic field strength of $5,500 \mathrm{G}$ for treating water which was used to irrigate okra plants and the effect on plant growth and yield was significant.

This study was carried out to determine whether magnetic treatment of the irrigation water may actually enhance vegetative growth and yield of tomato.

\section{Materials and Methods}

The study was carried out in the Department of Agricultural and Biosystems Engineering, University of Ilorin, Ilorin, Kwara State, Nigeria. Ilorin lies on the latitude $8^{\circ} 30^{1} \mathrm{~N}$ and longitude $45^{\circ} \mathrm{E}$ at an elevation of about $340 \mathrm{~m}$ above mean sea level (Ejieji and Adeniran, 2010). Ilorin is in the Southern Guinea Savannah Ecological zone of Nigeria with annual rainfall of about 1,300 $\mathrm{mm}$. The wet season begins towards the end of March and 
346

ends in October, while the dry season starts in November and ends in March (Ogunlela, 2009). The temperatures from the wet and dry bulb thermometer in the transparent garden shed where the tomato (variety UC82B) were grown between $23^{\text {rd }}$ September 2014 and $30^{\text {th }}$ January 2015 varied from 16.5 to 30 ${ }^{\circ} \mathrm{C}$ (wet bulb) and 23.3 to $38{ }^{\circ} \mathrm{C}$ (dry bulb) with relative humidity of 50 to $90 \%$.

A rectangular treatment chamber with an internal dimension of 1.5 by $4.6 \mathrm{~cm}$ and $100 \mathrm{~cm}$ long was used. The magnetic flux density measured between two magnetic cores without air gap varied from 700 to $4,310 \mathrm{G}$. The effective mean magnetic flux densities inside the rectangular treatment chamber when water was flowing through it were determined using gaussmeter and were 124,319 and $719 \mathrm{G}$ respectively. These three flux densities were used to treat the irrigation water and labeled as the treatments $T_{1}, T_{2}$ and $T_{3}$, compared with a control experiment $(\mathrm{Tc})$ which was not treated. The North and South poles of the electromagnetic cores on the treatment chamber seat in this study were alternated for effective treatment of irrigation water by the magnetic field (Gabrielli et al., 2000). The irrigation water was allowed to pass through the treatment chamber unit four (4) times for duration of 113 seconds with a circulation flowing method as shown in Fig. 1 and Fig. 2.

Determination of the water requirement by tomato plants and the irrigation interval

Water requirement of tomato plant is the amount of water

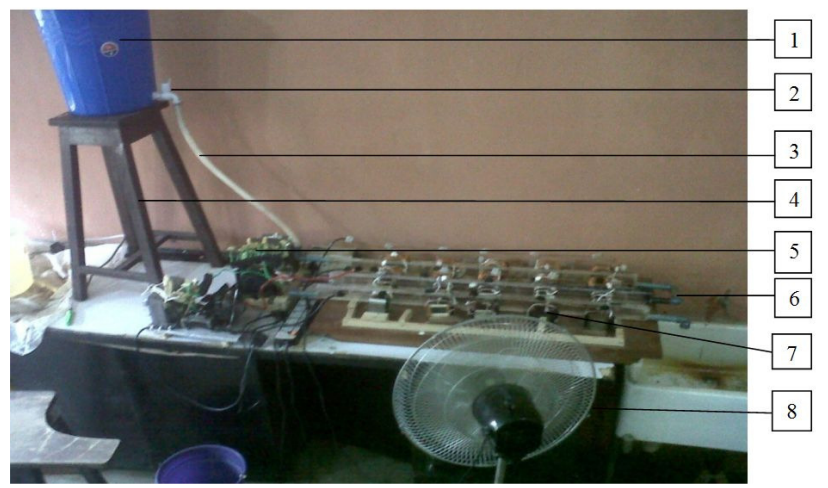

Fig. 1. Electromagnetic treatment system with a fan

1- water tank, 2- tap, 3- hose, 4- stood, 5- variable voltage device, 6-pipe, 7- electromagnet, 8- cooling fan

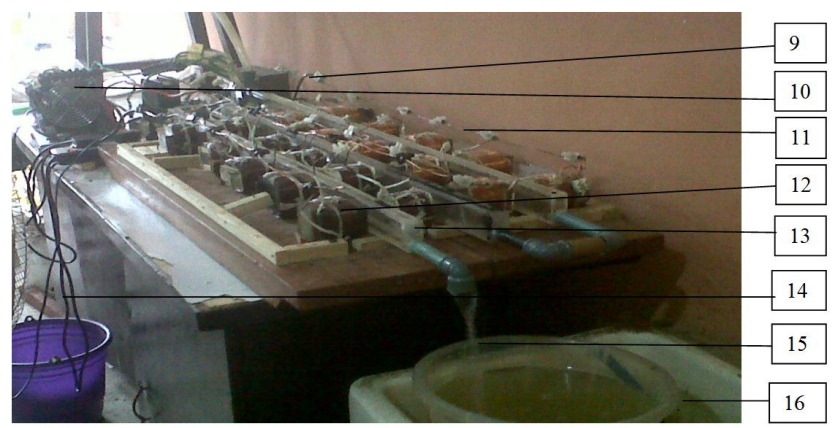

Fig. 2. Magnetically treated water from the electromagnet

9- positive terminal from variable voltage device, 10- variable voltage device, 11- distribution copper wire, 12- electromagnet with 180 turns of coil, 13- rectangular treatment chamber, 14- connecting wire to socket, 15- treated water from electromagnet, 16- bucket containing magnetically treated water. required to meet the required evapotranspiration, photosynthesis and metabolic process. Crop evapotranspiration, depth of water required to bring the soil to field capacity at the beginning of the experiment, available water, wilting point, net depth of irrigation, irrigation interval, volume of water required daily by tomato plants and volume of required in three (3) days irrigation interval for two stands of tomato plants were determined using equations (1), (2), (3), (4), (5), (6) and (7) respectively. The quantity of 1.30 liter of water was determined as the water required by two stands of tomato plants for 3 days irrigation interval.

$$
\begin{aligned}
& E T c=K_{c} \times E T_{o} \\
& D_{F}=\frac{\rho_{b}}{\rho_{w}}\left(\frac{F C-\Theta_{1}}{100}\right) D_{b} \\
& A W=\frac{\rho_{b}}{\rho_{w}}\left(\frac{F C-W P}{100}\right) D_{b} \\
& W P=\frac{F C}{F} \\
& I_{v}=\frac{d_{n}}{E T c} \\
& V_{d p}=K_{c} \times E T_{o} \times C_{c} \times A_{p} \\
& V_{d a y s}=V_{d p} \times N_{p} \times I_{v}
\end{aligned}
$$

Where: ETc is the crop evapotranspiration ( $\mathrm{mm} /$ day), $\mathrm{K}_{\mathrm{c}}$ is the crop coefficient, $\mathrm{ET}_{\mathrm{o}}$ is the reference evapotranspiration $\left(\mathrm{mm} /\right.$ day), $\mathrm{D}_{\mathrm{F}}$ is the depth required to bring moisture content to field capacity at the beginning of the experiment $(\mathrm{mm}), \rho_{b}$ is soil bulk density $\left(\mathrm{g} / \mathrm{cm}^{3}\right), \rho_{\mathrm{w}}$ is the density of water $\left(\mathrm{g} / \mathrm{cm}^{3}\right), \mathrm{FC}$ is the field capacity of the soil (\%), $\Theta$ is the moisture content of the soil prior to irrigation (\%), $\mathrm{D}_{\mathrm{b}}$ is depth of the bucket $(\mathrm{mm}), \mathrm{Aw}$ is the available water $(\mathrm{mm}), \mathrm{WP}$ is the wilting point $(\%), \mathrm{F}$ is a factor ranging from 2.0 - 2.4 depending on the percentage of silt in the soil. The value of $\mathrm{F}$ used was 2.2 and wilting point was calculated to be $12.26 \%$ when field capacity (FC) was $26.98 \%$. $\mathrm{I}_{\mathrm{v}}$ is the irrigation interval (day), $d_{n}$ is the net depth of irrigation $(\mathrm{mm}), \mathrm{V}_{\mathrm{dp}}$ is the volume of water required daily per plant (liter/day), $\mathrm{C}_{\mathrm{c}}$ is the crop canopy (\%), $A_{p}$ is the area of the bucket $\left(\mathrm{mm}^{2}\right)$ and $N_{p}$ is the number of tomato stand in a bucket or point.

$$
\begin{aligned}
& E T c=1.05 \times 4.7=4.94 \mathrm{~mm} / \text { day } \\
& D_{F}=\frac{1.433}{1.000}\left(\frac{26.98-5.23}{100}\right) \times 235=73.24 \\
& V_{F}=0.07324 X 0.054332=0.003979 \mathrm{~m}^{3}=3.979 \text { litres } \\
& A W=\frac{1.433}{1.000}\left(\frac{26.98-12.26}{100}\right) \times 235=49.57 \mathrm{~mm} \\
& d_{n}=\frac{30}{100} \times 49.57=14.871=14.87 \mathrm{~mm} \\
& I_{v}=\frac{14.87}{4.94}=3.010 \mathrm{~mm} / \text { day } \\
& V_{d p}=1.05 \times 4.7 \times 0.8 \times 0.054332=0.215 \text { litre } / \text { day } \\
& V_{3 \text { days }}=0.215 \times 2 \times 3=1.30 \text { litres }
\end{aligned}
$$

\section{Soilproperties}

The soil used in this study was loam sand with percentage contents of silt, calay and sand of 8.67, 5.76 and $85.57 \%$ respectively. The soil was mixed together properly after the soil analyses in order to have the same soil property. The chemical properties of the soil used were shown in Table 1 . The soil was filled into the bucket ( 21 buckets with 7 buckets for each treatment and 7 buckets for untreated water) to a depth (level) of $235 \mathrm{~mm}$ and the diameter of the bucket at that level was $235 \mathrm{~mm}$ $\left(A_{p}=0.05433 \mathrm{~m}^{2}\right)$. A completely randomized design (CRD) experimental layout was used for allocating the treatments in the transparent garden shed. 
Table 1. Physico-chemical properties of experimental soil

\begin{tabular}{lcccc}
\hline Element & Sample A & Sample B & Sample C & Mean \\
\hline $\mathrm{pH}$ & 6.0 & 5.8 & 5.6 & 5.8 \\
$\mathrm{~N}(\%)$ & 0.58 & 0.63 & 0.71 & 0.64 \\
$\mathrm{P}(\mathrm{mg} / \mathrm{kg})$ & 2.51 & 2.46 & 3.25 & 2.74 \\
$\mathrm{Ca}^{2+}(\mathrm{cmol} / \mathrm{kg})$ & 1.28 & 1.14 & 1.68 & 1.37 \\
$\mathrm{Mg}^{2+}(\mathrm{cmol} / \mathrm{kg})$ & 0.92 & 0.58 & 1.01 & 0.84 \\
$\mathrm{~K}^{+}(\mathrm{cmol} / \mathrm{kg})$ & 2.20 & 2.11 & 2.42 & 2.24 \\
$\mathrm{Na}^{+}(\mathrm{cmol} / \mathrm{kg})$ & 1.03 & 1.24 & 1.18 & 1.15 \\
Organic matter $(\%)$ & 1.56 & 1.15 & 1.22 & 1.31 \\
Organic carbon $(\%)$ & 0.90 & 0.67 & 1.01 & 0.86 \\
C.E.C $(\mathrm{meq} / 100 \mathrm{~g}$ of & 5.63 & 5.12 & 6.46 & 5.74 \\
soil) & & & & \\
\hline
\end{tabular}

\section{Results and Discussion}

Vegetative growth and stem diameter of tomato plants

The results of this study revealed that using magnetic flux densities of 124,319 and $719 \mathrm{G}$ for treating the irrigation water influenced the vegetative growth and stem diameter (thickness) of the tomato plants. Tomato plants which were irrigated with magnetically treated water grew faster and had bigger stem diameter than that of non-magnetized water as shown in Tables 2 and 3. Tomato plants irrigated with magnetized water also matured faster, with the first harvest occurred 74 days after planting, while harvesting started 85 days after planting with non-magnetically treated water plants. Reduction of time needed for plants to reach maturity (early maturity) when irrigated with magnetized water was in agreement with the research conducted by Mashehwari and Grewal (2009). The growth rate (height) of tomato plants irrigated with magnetically treated water was statistically significant compared with

Table 2. Mean height of the tomato plants recorded during the vegetative growth

\begin{tabular}{lcccc}
\hline \multirow{2}{*}{ Date } & \multicolumn{4}{c}{ Tomato plant height $(\mathrm{mm})$} \\
\cline { 2 - 5 } & $\mathrm{T}_{1}$ & $\mathrm{~T}_{2}$ & $\mathrm{~T}_{3}$ & $\mathrm{~T}_{\mathrm{C}}$ \\
\hline $19 / 10 / 2014$ & 154.3 & 178.6 & 199.3 & 137.1 \\
$25 / 10 / 2014$ & 302.1 & 325.0 & 330.0 & 243.6 \\
$30 / 10 / 2014$ & 446.4 & 453.6 & 457.9 & 345.7 \\
$03 / 11 / 2014$ & 515.0 & 532.0 & 530.0 & 407.9 \\
$09 / 11 / 2014$ & 560.0 & 556.4 & 588.6 & 469.3 \\
\hline $\mathrm{T}_{1}=124 \mathrm{G}, \mathrm{T}_{2}=319 \mathrm{G}, \mathrm{T}_{3}=719 \mathrm{G}$ and $\mathrm{T}_{\mathrm{C}}=0.0 \mathrm{G}$ & &
\end{tabular}

Table 3. Mean diameter of the tomato stems, measured $30 \mathrm{~mm}$ above the soil level

\begin{tabular}{|c|c|c|c|c|}
\hline \multirow{2}{*}{ Date } & \multicolumn{4}{|c|}{ Stem diameter $(\mathrm{mm})$} \\
\hline & $\mathrm{T}_{1}$ & $\mathrm{~T}_{2}$ & $\mathrm{~T}_{3}$ & $\mathrm{~T}_{\mathrm{C}}$ \\
\hline $01 / 11 / 2014$ & 6.21 & 6.43 & 6.19 & 5.09 \\
\hline $09 / 11 / 2014$ & 8.64 & 7.99 & 8.21 & 6.96 \\
\hline
\end{tabular}

Table 4. ANOVA for the height of tomato plants in the consumptive use experiment

\begin{tabular}{lccccc}
\hline $\begin{array}{l}\text { Source of } \\
\text { error }\end{array}$ & $\begin{array}{c}\text { Degree of } \\
\text { freedom } \\
(\mathrm{DF})\end{array}$ & $\begin{array}{c}\text { Sum of } \\
\text { square } \\
(\mathrm{SS})\end{array}$ & $\begin{array}{c}\text { Mean } \\
\text { square } \\
(\mathrm{MS})\end{array}$ & $\begin{array}{c}\text { Calculated } \\
\mathrm{F}\end{array}$ & $\begin{array}{c}\text { Tabular F } \\
\text { at } \mathrm{P} \leq 5 \%\end{array}$ \\
\hline Treatment & 3 & 558.50 & 186.17 & 8.07 & 2.78 \\
Error & 24 & 553.76 & 23.07 & & \\
\hline Total & 27 & $1,112.26$ & & & \\
\hline
\end{tabular}

tomato plants irrigated with non-magnetized water; calculated value of $F$ was 8.10 , while the table value of $F$ was 2.78 as shown by ANOVA test in Table 4 .

\section{Tomato yield}

The tomato yield after using three different magnetic flux densities are shown in Table 5 . The tomato yields from plants treated with the magnetically treated water at 124,319 and 719 G were $892.1,1075.8$ and 1045.7 g respectively, while the tomato yield from the non-magnetized water was $637.7 \mathrm{~g}$. It can be concluded that the magnetic flux density of $319 \mathrm{G}$ produced the highest yield. The variation of the tomato yield based on the magnetic flux densities was not statistically significant because the calculated value of $F\left(F_{\mathrm{cal}}=1.31\right)$ was less than the Table value $\left(\mathrm{F}_{\mathrm{Tab}}=2.78\right)$ as shown in Table 6 . This means that there was no much variation in the yields of tomato based on the three magnetic flux densities applied in the experiment to treat the irrigation water. On the other hand, the yields from magnetically treated water were all higher than the yield obtained from non-magnetically treated water. The percentage increment of the tomato yields were 39.9, 64.0 and $68.7 \%$ respectively when compared with the yield from the control experiment. The increment was in concordance with the findings of other researchers who concluded that magnetic treatment of irrigation water increased crop yield (Mahsehwari and Grewal, 2009; Hozayn and Qados, 2010; Moussa, 2010; Anand et al., 2012; Chern, 2012). The results of this study revealed that magnetic treatment of the irrigation water had effect on the vegetative growth of tomato plants and enhanced tomato yield (being obtained high yield as shown in Table 5), which is in agreement with the work done by Babu (2010) and El-Sayed and Sayed (2014).

The tomato plants irrigated with magnetically treated water contained fresh leaves and tomato fruits after 120 days from the beginning of the survey, while the tomato plants irrigated with non-magnetically treated water had dry leaves and very few tomato fruits as shown in Fig. 3 and Fig. 4.

Table 5. Tomato yield from the different magnetized water treatments

\begin{tabular}{lcccc}
\hline \multirow{2}{*}{ Row } & \multicolumn{4}{c}{ Tomato yield $(\mathrm{g})$} \\
\cline { 2 - 5 } & $\mathrm{T}_{1}$ & $\mathrm{~T}_{2}$ & $\mathrm{~T}_{3}$ & $\mathrm{~T}_{\mathrm{C}}$ \\
\hline 1 & 26.2 & 35.0 & 153.1 & 111.1 \\
2 & 160.5 & 45.6 & 210.4 & 81.1 \\
3 & 152.5 & 103.1 & 151.6 & 31.5 \\
4 & 150.9 & 223.1 & 124.3 & 10.0 \\
5 & 123.8 & 174.0 & 218.2 & 119.8 \\
6 & 159.0 & 304.5 & 78.1 & 115.6 \\
7 & 119.2 & 190.5 & 110.0 & 168.6 \\
Total & 892.1 & $1,075.8$ & $1,045.7$ & 637.7 \\
Mean & 127.44 & 153.69 & 149.39 & 91.10 \\
\hline \hline
\end{tabular}

$T_{1}=$ Magnetized water treated with $124 \mathrm{G}, \mathrm{T}_{2}=319 \mathrm{G}, \mathrm{T}_{3}=719 \mathrm{G}$ and $\mathrm{T}_{\mathrm{C}}=0.0$ G (Non-magnetized water). The tomatoes were planted on 23/09/2014 and harvesting was stopped on 30/01/2015 (tomato plants were monitored for 130 days).

Table 6. ANOVA for the yield of tomato in the consumptive use experiment

\begin{tabular}{lccccc}
\hline $\begin{array}{l}\text { Source of } \\
\text { error }\end{array}$ & $\begin{array}{c}\text { Degree of } \\
\text { freedom } \\
(\mathrm{DF})\end{array}$ & $\begin{array}{c}\text { Sum of } \\
\text { square (SS) }\end{array}$ & $\begin{array}{c}\text { Mean } \\
\text { square } \\
(\mathrm{MS})\end{array}$ & $\begin{array}{c}\text { Calculated } \\
\mathrm{F}\end{array}$ & $\begin{array}{c}\text { Tabular } \\
\text { Fat } \\
5 \%\end{array}$ \\
\hline Treatment & 3 & $17,191.05$ & $5,730.35$ & 1.31 & 2.78 \\
Error & 24 & $105,056.00$ & $4,377.33$ & & \\
Total & 27 & $122,247.05$ & & & \\
\hline
\end{tabular}


348

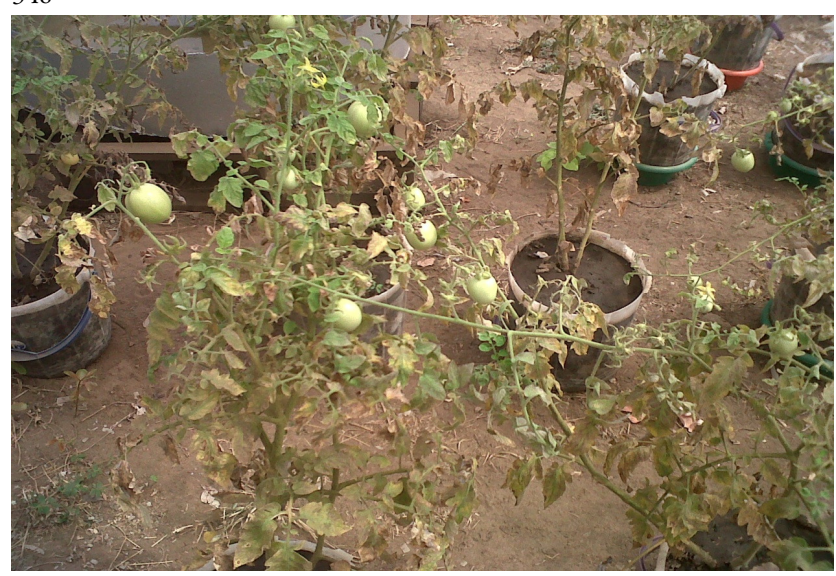

Fig. 3. Tomato plant irrigated with magnetic treated water after 120 days with more fresh leaves and tomato fruits

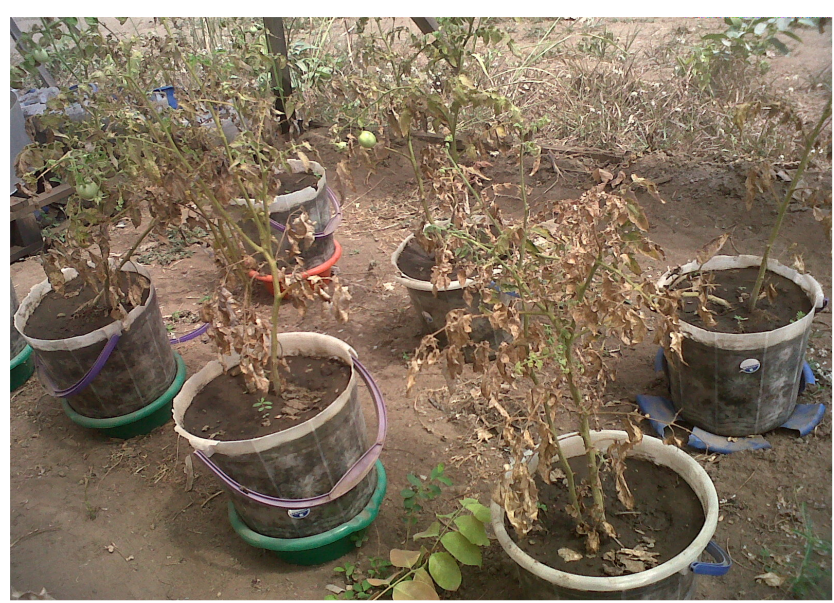

Fig. 4. Tomato plant irrigated with non - magnetic treated water after 120 days with few fresh leaves and fruits but more dry leaves

\section{Conclusions}

Magnetic treatment of the irrigation water (magnetically treated water) influenced the vegetative growth of tomato by increasing the rate of growth, reducing the time until maturity and increased the yield of tomato by 39.9 to $68.7 \%$. Magnetic flux densities of 124,319 and $719 \mathrm{G}$ inside the treatment chamber (pipe) or 700 to $4,300 \mathrm{G}$ between two magnetic cores without air gap were adequate for the treatment of irrigation water and improved the tomato yield.

\section{References}

Anand A, Nagarajan S, Verma APS, Joshi DK, Pathak PC, Bhardwaj J (2012). Pre-treatment of seeds with static magnetic field ameliorates soil water stress in seedling of maize (Zea mays L.). Indian Journal of Biochemistry and Biophysics 49(1):63-70.

Babu C (2010). Use of magnetic water and polymer in agriculture. Tropical Research ID 08- 806-001.

Chern CC (2012). Application of magnetic water to stimulate the lady's finger (Abelmosculentus L.) moench plant growth. PhD Thesis, University of Technology, Malaysia.

Ejieji CJ, Adeniran KA (2010). Effects of water and fertilizer stress on the yield, fresh and dry matter production of grain Amaranth ('Amaranthus cruentus'). Australian Journal of Agricultural Engineering 1(1):18-24.

El-Sayed H, Sayed A (2014). Impact of magnetic water irrigation for improve the growth, chemical composition and yield production of broad bean (Vicia faba L.) plant. American Journal of Experimental Agriculture 4(4):476496.

Gabrielli C, Jaouhari R, Maurin G, Keddam M (2000). Magnetic water treatment for scale prevention. Elsevier Science 35(13):3249-3259.

Higashitani K, Kage A, Katamura S, Imai K, Hatade S (1993). Effects of a magnetic field on the formation of $\mathrm{CaCO}_{3}$ particles. Colloid and Interface Science 156(1):90-95.

Hozayn M, Qados AMSA (2010). Irrigation with magnetized water enhances growth, chemical constituent and yield of chickpea (Circer arietinum L.). Agriculture and Biology Journal of North America 1(4):671-676.

Kochmarsky V (1996). Magnetic treatment of water: possible mechanisms and conditions for applications. Magnetic and Electrical Separation (7):77-107.

Kronenberg KJ (1985). Experimental evidence for effects of magnetic fields on moving water. IEEE Transactions on Magnetics 21(5):2059-2061.

Maheshwari RL, Grewal HS (2009). Magnetic treatment of irrigation water: its effects on vegetable crop yield and water productivity. Journal of Agricultural Water Management 96(8):1229-1236.

Moussa HR (2011). The impact of magnetic water application for improving common bean (Phaseolus vulgaris L.) production. New York Science Journal 4(6):15-20.

Muraji M, Asai T, Tatebe W (1998). Primary root growth rate of Zea mays seedlings grown in an alternating magnetic field of different frequencies. Bioelectrochemistry and Bioenergetics 44(2):271-273.

Noran R, Shani U, Lin I (1996). The effect of irrigation with magnetically treated water on the translocation of minerals in the soil. Magnetic and Electrical Separation (7):109-122.

Ogunlela AO (2009). Stochastic analysis of rainfall events in Ilorin, Nigeria. Journal of Agricultural Research and Development 1(1):39-50.

Podlesny J, Pietruszewski S, Podleoena A (2004). Efficiency of the magnetic treatment of broad bean seeds cultivated under experimental plot conditions. International Agrophysics 18:65-71.

Suchitra K, Babu EA (2011). A pilot study on silt magnetized and non-magnetized water in the on-farm water use efficiency management. Centre for Water Resources, Anna University, Chennai, India. 